\title{
Influence of Rhizobia Inoculation and Rock-Phosphate on Biomass and Nitrogen Content of Leucaena leucocephala (Lam.) De Wit Seedlings
}

\author{
Marwa G. S. Frahat ${ }^{1}$, Ahmed A. A. El-Settawy ${ }^{1}$, and Mohamed R. A. Shehata ${ }^{2}$
}

\begin{abstract}
The study was carried out in the nursery of the Experimental Station of Forestry and Wood Technology Department, Faculty of Agriculture, Alexandria University during the period from $1^{\text {st }}$ May, 2017 to $31^{\text {st }}$ March, 2018. It aimed at evaluating the influence of two races of Rhizobium (TAL82 and TAL582) on the overall biomass and the total $N$ content in the leaves of Leucaena leucocephala seedlings. In addition, the study aimed at finding out, if any, the impact of rock-phosphate (RF) amendment on the nodulation and growth efficiency of $L$. leucocephala seedlings. Seedlings were inoculated with pure cultures of both strains, then fertilized with rockphosphate on $7^{\text {th }}$ October, 2017 using 4 levels; 0.0, 0.5, 1.0 and 2.0g / kg soil. Both strains (TAL82 and TAL582) developed typical nodules. However, solubility of RF potential was affected by the strain tested as expressed in terms of growth parameters. The strain TAL582 showed, better and faster growth promoting effect than TAL82 in L. Leucocephala seedlings. The fertilization with $P$ induced promoting nodule formation earlier than unamended control. Results showed that fertilization with $1 \mathrm{~g}$ RF/ kg soil is more effective than the higher tested level (2g RF/ $\mathrm{Kg}$ soil). Therefore, it is recommended to inoculate seedlings of L. Leucocephala with Rhizobium particularly TAL582 strain and to add $P$ as a fertilizer at the rate of $1 \mathrm{gRF} / \mathrm{Kg}$ soil to achieve the best plant growth in significant short time.
\end{abstract}

Key words: Rhizobium, rock phosphate, Leucaena leucocephala, nitrogen fixation, nodulation, PGPR.

\section{INTRODUCTION}

Leucaena leucocephala(Lam.) de Wit, often referred to as the "wonder tree", is a widely used woody legume species in the tropical and sub-tropical forests (Orwa et al., 2009) and is an efficient means for sustaining the productivity of agroforestry systems (Shelton, 1998). It is well known that multipurpose legume tree species like Leucaena are important for ecosystem restoration and agroforestry.

Leucaena is a genus of the subfamily Caesalpinioideae, which belongs to the legume family Fabaceae. It contains about 24 species of trees and shrubs, which are commonly known as lead trees (Mabberley 1997). They are native to the Americas,

\footnotetext{
${ }^{1}$ Forestry and Wood Technology Department, Faculty of Agriculture, Alexandria University.

${ }^{2}$ Plant Pathology Departments, Faculty of Agriculture,

Alexandria University.

Received November 18, 2018, Accepted December 30, 2018
}

ranging from Texas in the United States south to Peru. The generic name is derived from the Greek word (leukos), meaning "white," referring to the flower's color (Glen and Hugh 2004).

Lead tree is valued as an excellent protein source for cattle fodder, consumed browsed or harvested, mature or immature, green or dry. The nutritive value is equal or superior to alfalfa. Lead tree has gained a favorable reputation in land reclamation, erosion control, water conservation, reforestation and soil improvement programs, and is a good cover and green manure crop.

Leguminous plants play an important role in ecosystem productivity and diversity due to their association with nitrogen (N)-fixing diazotropic soil bacteria called Rhizobium (Thrall et al., 2011). This symbiosis can increase plant biomass (Spehn et al., 2002) and mitigate land degradation through the use of fast-growing $\mathrm{N}$-fixing trees or shrub "pioneers" in restoration plantations (Miles et al., 2006).

Bacteria of the genus Rhizobium play a very important role in agriculture by inducing nitrogen-fixing nodules on the roots of many legumes. This symbiosis can relieve the requirements for added nitrogenous fertilizer during their growth.

Many factors, such as cultural practices, weather and soil conditions, may affect the survivability of the carryover Rhizobium in the soil. Therefore, inoculating the plant is considered as a good practice that the plant will be able to grow to its maximum potential and compete (Deaker et al. , 2004; Elkhatib, 2009).

$\mathrm{N}$ fixation occurs mostly in root nodules that provide an environment where symbiotic bacteria alter atmospheric nitrogen into ammonia. Plants provide organic-acids as an energy source and in exchange are supplied with fixed N (Miller et al., 2007). Variations in plant-rhizobia interactions can affect the successful establishment of legume trees during early developmental stages (i.e., seedlings) (Tharall et al., 2011) and can influence the benefit gained from the symbiosis. Such benefits are usually evaluated based on growth parameters and nutrients content, which measured in the plantnotably, total plant biomass, $\mathrm{N}$ content in plant organ, nodules (e.g., number of nodules, 
nodule biomass and nodule root ratio) or nodule physiological parameters (e.g., apparent nitrogenase activity in relation to respiration).

Phosphorus $(\mathrm{P})$ enhances the symbiotic nitrogen $(\mathrm{N})$ fixation process in legume crops. Generally, legumes require more $\mathrm{P}$ than grasses for root development and energy driven processes. Phosphorus is an essential ingredient for Rhizobium bacteria to convert atmospheric $\mathrm{N}$ (N2) into an ammonium (NH4) form useable for plants. Rhizobium are able to synthesize the enzyme nitrogenase, which catalyzes the conversion of $\mathrm{N} 2$ to two molecules of ammonia (NH3). The pink color, typical of healthy and effective nodules, is due to the presence of a protein called leghemoglobin. This special protein contains both iron $(\mathrm{Fe})$ and molybedenum (Mo) and is responsible for binding oxygen. This creates a low oxygen environment within the nodule, which allows Rhizobium bacteria to survive and to fix N2. Phosphorus becomes involved as an energy source.

In this study, our aimed were to evaluate the influence of Rhizobium`s races on the overall biomass and the total $\mathrm{N}$ content in plant leaves and to find out, if any the impact of rock-phosphate amendment on the nodulation and plant growth efficiency of $L$. Leucocephala seedlings.

\section{MATERIALS AND METHODS}

The study was carried out at the nursery of the Experimental Station of Forestry and Wood Technology Department, Faculty of Agriculture, Alexandria University during the period from $1^{\text {st }}$ May, 2017 to $31^{\text {st }}$ March, 2018.

\section{Experimental Material}

\section{Tree species}

Fresh certified seeds of Leucaena leucocephala trees, collected from Antoniadis Botanical Garden, Alexandria.

\section{Soil}

Sandy clayey soil was used, obtained from nursery of Experimental Station of the Department, Abies, Alexandria.

\section{Fertilizer type}

Rock-phosphate (RP), contained $14 \% \mathrm{P}$ was used in the experiment.

\section{Rhizobium}

Pure cultures of Rhizobium of races designated TAL82 and TAL582 were separately blended and added to sterilized peat then kept in refrigerator at $5^{\circ} \mathrm{C}$ for 5 days till using.

\section{Experimental procedure (Methodology)}

Seeds of L. leucocephala were soaked in hot $\left(90{ }^{\circ} \mathrm{C}\right.$, then kept in cold water for 24 hours as pretreatment to overcome its seed coat dormancy and to accelerate their germination.

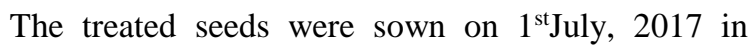
plastic bags of $30 \mathrm{~cm}$ in height and $20 \mathrm{~cm}$ in diameter contained $3.7 \mathrm{~kg}$ of sterilized soil. After seed germination, the seedlings were irrigated daily during the first three months, then every 2 days to replenish the water consumption deficits. The average of water amount used in each irrigation was about $250 \mathrm{ml}$ of tap water.

Pure cultures of each of Rhizobium of two races designated TAL82 and TAL582 were blended and added to sterilized peat then kept in refrigerator at $5^{\circ} \mathrm{C}$ for 5 days. Seedlings were inoculated with about $3 \mathrm{~g}$ of a sterilized peat containing each one of the two races

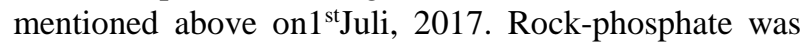
applied on $7^{\text {th }}$ October, 2017 at four levels; 0.0, 0.5, 1.0 and $2.0 \mathrm{~g} / \mathrm{kg}$ soil.

Control seedlings were also inoculated, but with sterilized (Previously autoclaved) inocula using the same method for the other treatment. Seedling heights were measured just after inoculation to determine growth rate of 2 week intervals until the end of the experiment span, on $31^{\text {st }}$ March, 2018.

\section{Soil analysis}

The main chemical and physical properties of the soil were determined as follows: The electrical conductivity (EC) of the saturated soil paste extract was measured using a conductimeter (GLP 31). Furthermore, $\mathrm{pH}$ of the soil was measured for the saturated soil-water suspension using a pH-meter (GLP 21) (Rhoades, 1982).

Water soluble ions were determined in the saturated soil paste extract; calcium and magnesium were determined by versenate method, sodium and potassium by a flame photometer, bicarbonate and carbonate by titration with dilute hydrochloric acid and chloride by silver nitrate method (Richard,1954).

\section{Nodulation assessment}

Root nodule formation was checked in harvested seedlings. The number of nodules per plant, nodule dry weights and nodule/ root ratio were determined.

\section{Growth parameters}

Shoot height $(\mathrm{cm})$, shoot growth rate $(\mathrm{cm} /$ month) and dry weight of the seedlings $(\mathrm{g})$ were determined during and at the end of the experiment.

At the end of the experiment, seedlings were extracted carefully from the bags, then roots were washed gently with tap water. Each seedling was divided 
into root and shoot (leaves and stem) either with nodules or without and their fresh weight were determined then oven-dried at $70^{\circ} \mathrm{C}$ for 48 hours to reach a constant weight to determine their dry weight.

\section{The experimental design}

A Complete randomized design (CRD) was used in this experiment. The split plot technique was used in analyzing the data obtained, where the main plot was for fertilization with phosphorus, while the sub plot was for the impact of inoculation with Rhizobium. The experimental data was statistically analyzed as it described by Snedecor (1956), using SAS ver. 9.1.3 (2007).

\section{RESULTS}

\section{Nodulation}

\subsection{Nodule number (NN)}

Examining the inoculated roots, seedlings treated with TAL582 (R2) had displayed the NN higher significantly that the strain TAL82 did (R1), particularly under the higher levels of rock phosphate. Nevertheless, the inoculated seedlings with R2 and fertilized with $1.0 \mathrm{~g}$ $\mathrm{RP} / \mathrm{kg}$ soil brought about the highest $\mathrm{NN}$, since it was 14.0 nodules/ plant, followed by the unfertilized seedlings inoculated with R1(13.25 nodules/ plant) (Table 1).

\subsection{Nodule dry weight (NDW) (g)}

It was found that the fertilized seedlings with $1.0 \mathrm{~g}$ $\mathrm{RP} / \mathrm{kg}$ (P2) soil and inoculated with R2 of Rhizobium had displayed the highest value of NDW, since it was $0.21 \mathrm{~g}$, followed by thosefertilized seedlings with $0.5 \mathrm{~g}$ $\mathrm{RP} / \mathrm{kg}$ soil and inoculated with R2(0.21g) (Table, 2).

\subsection{Nodule root ratio (NRR)}

The unfertilized -inoculated seedlings with Race 1 had brought about the highest value of NRR, since it was 0.08 , (Table 3 ).

\section{Nodules ultrastructure}

The examination of nodules using scanning electron microscope (SEM) has manifested the presence of bacteroid (bacteria enclosed with membrane) in mature infected cell (Fig. 1). In addition, starch granules were found almost colonizing the pranchymatous cells (Fig. 2) of the nodule of the two tested races of Rhizobium.

The examination of late senescent infected cell indicated the presence of multiple crystals occupying nodule cell (Fig. 3).

Table 1. Nodule number (NN) (nodule/ plant) of the inoculated and uninoculated seedlings of Leucaena leucocephala with Rhizobium which fertilized and unfertilized with rock-phosphate

\begin{tabular}{lccccc}
\hline & P0 & P1 & P2 & P3 & Mean \\
\hline R1 (TAL82) & 13.25 & 10.5 & 10.5 & 8.75 & 10.75 \\
R2 (TAL582) & 10 & 10.75 & 14 & 12.25 & 11.75 \\
Mean & 11.63 & 10.63 & 12.25 & 10.50 & \\
\hline
\end{tabular}

LSD P=----- $\quad$ LSD R $=----\quad$ LSD PR $=0.5254$

P0: 0.00 RF P1: 0.5gRF P2: $1.0 \mathrm{gRF} \quad$ P2: $2.0 \mathrm{~g} \mathrm{RF}$

Table 2. Nodule dry weight (g) in the roots of the inoculated and uninoculated seedlings of Leucaena leucocephala with Rhizobium which fertilized and unfertilized with rock-phosphate

\begin{tabular}{lccccc}
\hline & P0 & P1 & P2 & P3 & Mean \\
\hline R1 (TAL82) & 0.12 & 0.15 & 0.1 & 0.02 & 0.10 \\
R2 (TAL582) & 0.15 & 0.17 & 0.21 & 0.05 & 0.15 \\
Mean & 0.14 & 0.16 & 0.16 & 0.04 & \\
\hline
\end{tabular}

LSD P=----- $\quad$ LSD R=0.014 LSD PR=0.1201

P0: 0.00g RF P1: 0.5gRF P2: $1.0 \mathrm{gRF} \quad$ P2: $2.0 \mathrm{~g} R \mathrm{RF}$

Table 3. Nodule root ratio of the inoculated and uninoculated seedlings of Leucaena leucocephala with Rhizobium which fertilized and unfertilized with rock-phosphate

\begin{tabular}{lccccc}
\hline & P0 & P1 & P2 & P3 & Mean \\
\hline R1 (TAL82) & 0.08 & 0.05 & 0.05 & 0.01 & 0.0475 \\
R2 (TAL582) & 0.04 & 0.05 & 0.04 & 0.01 & 0.035 \\
Mean & 0.06 & 0.05 & 0.045 & 0.01 & \\
\hline
\end{tabular}

\begin{tabular}{llll}
\hline LSD P $=----$ & LSD R=0.254 & LSD PR=0.0042 & \\
P0: 0.00 RF & P1: 0.5gRF & P2: $1.0 \mathrm{~g} \mathrm{RF}$ & P2: $2.0 \mathrm{~g} \mathrm{RF}$
\end{tabular}




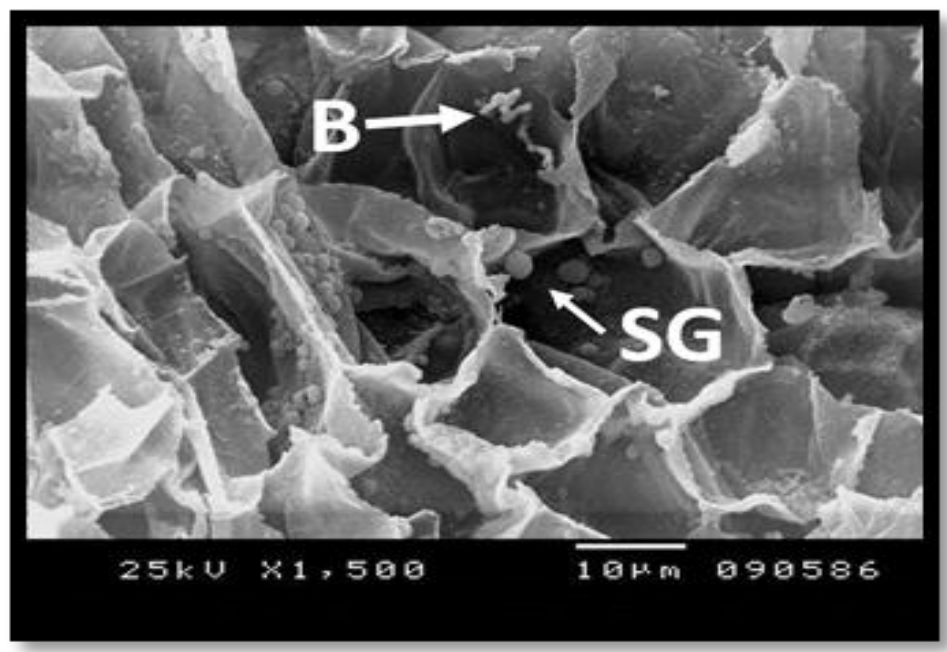

Fig. 1. Mature- infected parenchymateous cells with bacteroid (B), starch granule (SG) in the nodule cell.

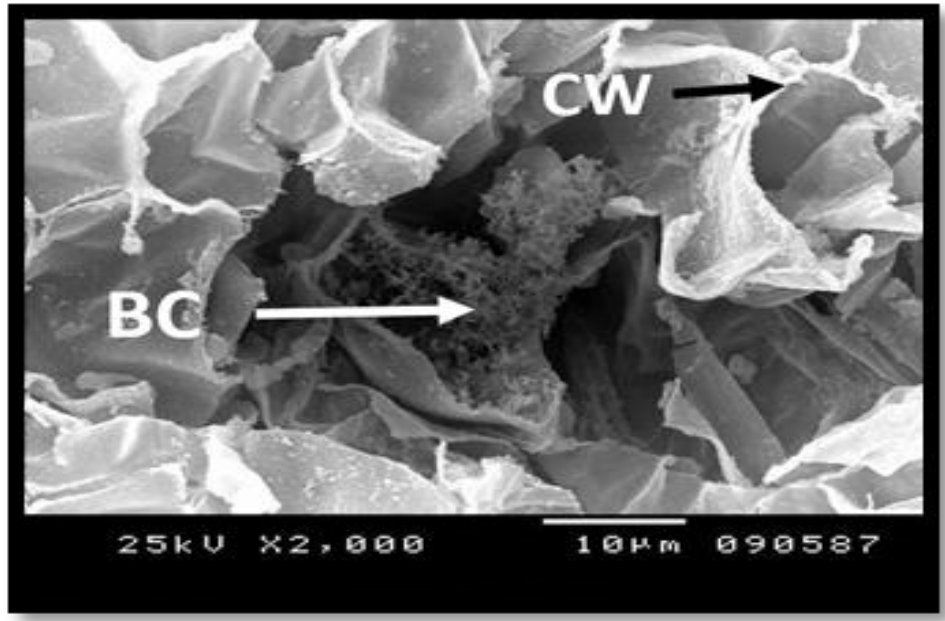

Fig. 2. SEM of an early senescent infected cell of nodule indicated bacterial cell (BC). CW is a cell wall of nodule cell.

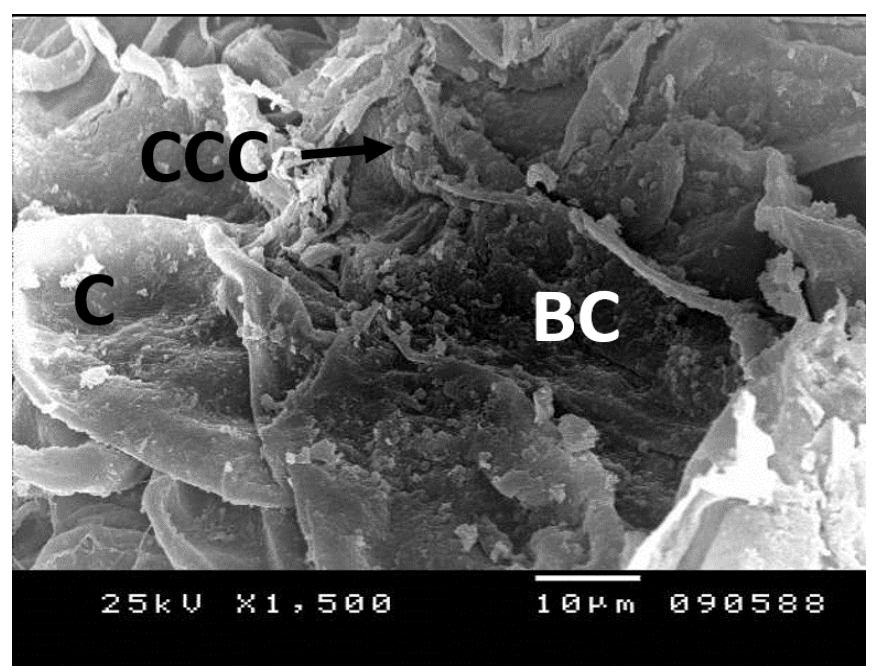

Fig. 3. SEM of late senescent infected cell indicated crystal (C) occupying the cell besides bacterial cells (BC) and chambered cells with crystals (CCC). 


\section{Growth parameters}

\subsection{Shoot height (SH)}

The analysis of the significant interaction between fertilization with RP and inoculation with Rhizobium has revealed that the inoculated seedlings with $\mathrm{R} 2$ and fertilized with1.0g RP $\backslash \mathrm{kg}$ soil displayed the highest $\mathrm{SH}$ $(98.00 \mathrm{~cm})$, yet the uninoculated seedlings (control) which fertilized with the same level of $\mathrm{P}$ have exhibited the lowest $\mathrm{SH}(49.50 \mathrm{~cm})$

\subsection{Shoot growth rate $(\mathrm{SGR})(\mathrm{cm} / \mathrm{month})$}

The statistical analysis of variance has revealed that the positive impact of inoculation with the two races of Rhizobium was of SGR seedlings.

Regarding the significant interaction between Rhizobium and RP fertilizers, it was found that the highest SGR was obtained in the case of inoculated seedlings with R2 and fertilized with $1.0 \mathrm{~g} \mathrm{RP} / \mathrm{kg}$ soil, since it was $7.13 \mathrm{~cm} /$ month, which accounted for more than 2 folds of the uninoculated- fertilized seedlings with $2.0 \mathrm{~g} \mathrm{RP} \backslash \mathrm{kg}$ soil, since it was $2.42 \mathrm{~cm} /$ month (Table, 5).

\subsection{Root dry weight (RDW) (g).}

Considering, the significant interaction between the inoculation with Rhizobium and fertilization with phosphorus, the inoculated seedlings with TAL 582 which fertilized with $2 \mathrm{~g}$ RP exhibited the highest RDW, since it was $5.54 \mathrm{~g}$, while the lowest RDW was obtained in the uninoculated -unfertilized seedlings (control) (1.41g) (Table 6).

\subsection{Leaf dry weight (LDW) (g)}

The fertilized seedlings with $2.0 \mathrm{~g} \mathrm{RP} / \mathrm{Kg}$ soil have brought about the highest LDW, since it was $3.80 \mathrm{~g}$. The inoculated seedlings with TAL82and fertilized with $2.0 \mathrm{~g}$ $\mathrm{RP} / \mathrm{kg}$ soil had brought about the highest LDW (5.42g)as compared to that uninoculated - fertilized seedlings with $1.0 \mathrm{~g} / \mathrm{kg}$ RP which was $(1.71 \mathrm{~g})($ Table, 7$)$.

\subsection{Shoot dry weight (SDW) (g)}

It was found that the highest SDW was obtained in inoculated seedlings with R2 which fertilized with $1.0 \mathrm{~g}$ $\mathrm{RP} / \mathrm{kg}$ soil, since it was $14.78 \mathrm{~g}$, whereas the unfertilized seedlings and inoculated with R1 displayed the lowest SDW since the average was $(6.06 \mathrm{~g})$ (Table, 8$)$.

Table 4. Shoot height $(\mathrm{cm})$ of the inoculated and uninoculated seedlings of Leucaena leucocephala with Rhizobium which fertilized and unfertilized with rock-phos phate

\begin{tabular}{lccccc}
\hline & P0 & P1 & P2 & P3 & Mean \\
\hline C & 55.75 & 65.00 & 49.50 & 44.25 & $53.63 \mathrm{~b}$ \\
R1 (TAL82) & 68.50 & 74.50 & 59.75 & 80.00 & $70.69 \mathrm{~b}$ \\
R2 (TAL582) & 74.00 & 91.00 & 98.00 & 80.75 & $85.94 \mathrm{a}$ \\
Mean & 66.08 & 76.83 & 69.08 & 68.33 & \\
\hline
\end{tabular}

LSD P=----- $\quad$ LSD R=4.429 LSD PR=13.26

P0: $0.00 \mathrm{RF} \quad \mathrm{P} 1: 0.5 \mathrm{gRF} \quad \mathrm{P} 2: 1.0 \mathrm{~g} \mathrm{RF} \quad \mathrm{P} 2: 2.0 \mathrm{~g} \mathrm{RF}$

Table 5. Shoot growth rate $(\mathrm{cm} /$ month) of the inoculated and uninoculated seedlings of Leucaena leucocephala with Rhizobium which fertilized and unfertilized with rock-phosphate

\begin{tabular}{lccccc}
\hline & P0 & P1 & P2 & P3 & Avr \\
\hline C & 3.50 & 3.79 & 3.04 & 2.42 & $3.19 \mathrm{~b}$ \\
R1 (TAL82) & 5.00 & 2.79 & 3.96 & 6.08 & $4.46 \mathrm{a}$ \\
R2 (TAL582) & 5.33 & 5.83 & 7.13 & 5.96 & $6.06 \mathrm{a}$ \\
Avr & 4.61 & 4.14 & 4.71 & 4.82 & \\
\hline
\end{tabular}

LSD P= ---- LSD R= 1.155 LSD PR=0.211

P0: $0.00 \mathrm{~g} R \mathrm{RF} \quad \mathrm{P} 1$ : $0.5 \mathrm{gRF} \quad \mathrm{P} 2: 1.0 \mathrm{~g}$ RF $\quad$ P2: $2.0 \mathrm{~g}$ RF

Table 6. Root dry weight (RDW) (g) of the inoculated and uninoculated seedlings of Leucaena leucocephala with Rhizobium which fertilized and unfertilized with rock-phosphate

\begin{tabular}{lccccc}
\hline & P0 & P1 & P2 & P3 & Mean \\
\hline C & 1.41 & 1.54 & 1.94 & 0.89 & $1.45 \mathrm{c}$ \\
R1 (TAL82) & 1.45 & 3.05 & 2.08 & 3.22 & $2.45 \mathrm{~b}$ \\
R2 (TAL582) & 3.48 & 3.74 & 4.77 & 5.54 & $4.38 \mathrm{a}$ \\
Mean & $2.11 \mathrm{~b}$ & $2.78 \mathrm{~b}$ & $2.93 \mathrm{~b}$ & $3.22 \mathrm{a}$ & \\
\hline
\end{tabular}

LSD P $=0.748 \quad$ LSD R $=0.859 \quad$ LSD PR $=1.405$

P0: $0.00 \mathrm{~g} R \quad$ P1: $0.5 \mathrm{gRF} \quad$ P2: $1.0 \mathrm{~g}$ RF $\quad$ P2: $2.0 \mathrm{~g} R F$ 
Table 7. Leaf dry weight (LDW) (g) of the inoculated and uninoculated seedlings of Leucaena leucocephala with Rhizobium which fertilized and unfertilized with rock-phosphate

\begin{tabular}{lccccc}
\hline & P0 & P1 & P2 & P3 & \\
\hline C & 3.08 & 3.54 & 1.71 & 2.33 & $2.67 \mathrm{~b}$ \\
R1 (TAL82) & 2.75 & 3.38 & 3.25 & 5.42 & $3.70 \mathrm{a}$ \\
R2 (TAL582) & 3.07 & 3.40 & 3.03 & 3.65 & $3.29 \mathrm{a}$ \\
& 2.96 & 3.44 & 2.66 & 3.80 & \\
\hline
\end{tabular}

LSD P= ---- $\quad$ LSD R=1.254 LSD PR $=1.248$

P0: $0.00 \mathrm{~g} R F \quad P 1: 0.5 \mathrm{gRF} \quad$ P2: $1.0 \mathrm{~g} R \mathrm{RF} \quad \mathrm{P} 2: 2.0 \mathrm{~g} \mathrm{RF}$

\subsection{Total dry weight (TDW) (g)}

It is worthy to say that the inoculated seedlings with $\mathrm{R} 2$ and fertilized with $1.0 \mathrm{~g} \mathrm{RP} / \mathrm{kg}$ soil displayed the highest TDW (19.55g) as it compared to that of uninoculated and fertilized with $1.0 \mathrm{~g}$ RP $(5.42 \mathrm{~g})$ (Table 9).

\section{Mineral contents}

\subsection{Nitrogen content \% (N\%)}

The inoculated seedlings with R2 exhibited the highest N\% in the leaves, since it was 3.96\%. (Fig. 4).

Upon the significant interaction between the inoculation with Rhizobium and fertilization with RP, the fertilized seedlings with $1.0 \mathrm{~g} / \mathrm{kg}$ soil which inoculated with R2 had displayed the highest $\mathrm{N} \%$ (4.98\%)compared to that of inuninoculated and fertilized ones with $1.0 \mathrm{gRF} / \mathrm{kg}$ soil( $1.55 \%)$ (Table 11).

\section{DISCUSSION}

Upon the findings of this experiment, it can be said that the nitrogen fixation efficiency is different between the two tested strains. This might be due to the fact that the growth promoting effect of TAL582 was higher than that of TAL82, and it might also be due to the difference in phosphate solubilizing capabilities between the two strains. Phosphate solubilizing capability was believed to be closely related to the kind of organic acids secreted by different strains. This is in agreement with Zhang $e t$ al.(2013) who found that phosphate solubilizing capability of various bacteria was significantly different.

Table 8. Shoot dry weight (SDW) (g) of the inoculated and uninoculated seedlings of Leucaena leucocephala with Rhizobium which fertilized and unfertilized with rock-phosphate

\begin{tabular}{lccccc}
\hline & P0 & P1 & P2 & P3 & \\
\hline C & 6.12 & 5.83 & 3.48 & 4.14 & $4.89 \mathrm{c}$ \\
R1 (TAL82) & 6.06 & 9.41 & 7.42 & 9.71 & $8.15 \mathrm{~b}$ \\
R2 (TAL582) & 9.70 & 9.42 & 14.78 & 13.62 & $11.88 \mathrm{a}$ \\
& $7.29 \mathrm{~b}$ & $8.22 \mathrm{~b}$ & $8.56 \mathrm{~b}$ & $9.16 \mathrm{a}$ & \\
\hline
\end{tabular}

\begin{tabular}{llll}
\hline LSD P $=0.525$ & LSD R=1.386 & LSD PR=3.15 & \\
P0: $0.00 \mathrm{~g}$ RF & P1: $0.5 \mathrm{gRF}$ & P2: $1.0 \mathrm{~g}$ RF & P2: $2.0 \mathrm{~g}$ RF
\end{tabular}

Table 9. Total dry weight (TDW) (g) of the inoculated and uninoculated seedlings of Leucaena leucocephala with Rhizobium which fertilized and unfertilized with rock-phosphate

\begin{tabular}{lccccc}
\hline & P0 & P1 & P2 & P3 & \\
\hline C & 7.53 & 7.36 & 5.42 & 5.03 & $6.33 \mathrm{c}$ \\
R1 (TAL82) & 7.51 & 12.46 & 9.50 & 12.93 & $10.60 \mathrm{~b}$ \\
R2 (TAL582) & 13.18 & 13.16 & 19.55 & 18.16 & $16.01 \mathrm{a}$ \\
& $9.41 \mathrm{~d}$ & $10.99 \mathrm{c}$ & $11.49 \mathrm{~b}$ & $12.04 \mathrm{a}$ & \\
\hline
\end{tabular}

LSD P $=0.423 \quad$ LSD R $=1.7225 \quad$ LSD PR $=4.101$

P0: 0.00g RF P1: $0.5 \mathrm{gRF} \quad$ P2: $1.0 \mathrm{~g} R \mathrm{RF} \quad \mathrm{P} 2: 2.0 \mathrm{~g}$ RF

Table 10. Nitrogen content \% (N\%) in the leaves of the inoculated and uninoculated seedlings of Leucaena leucocephala with Rhizobium which fertilized and unfertilized with rock-phosphate

\begin{tabular}{lccccc}
\hline & P0 & P1 & P2 & P3 & Mean \\
\hline C & 1.62 & 1.55 & 2.11 & 2.43 & 1.93 \\
R1 (TAL82) & 3.63 & 3.25 & 4.47 & 3.88 & 3.81 \\
R2 (TAL582) & 3.41 & 3.76 & 4.98 & 3.70 & 3.96 \\
Mean & 2.89 & 2.85 & 3.85 & 3.33 & \\
\hline
\end{tabular}

LSD P $=0.0034 \quad$ LSD R=0.0074 LSD PR $=0.0147$

P0: $0.00 \mathrm{~g} R \quad$ P1: $0.5 \mathrm{gRF} \quad$ P2: $1.0 \mathrm{~g} R \mathrm{RF} \quad \mathrm{P} 2: 2.0 \mathrm{~g} \mathrm{RF}$ 


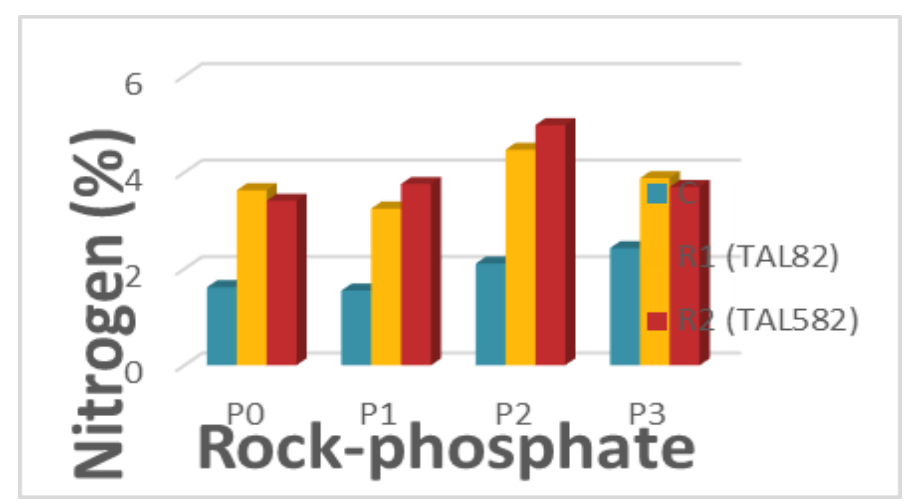

Fig. 4. Nitrogen content $\%(\mathrm{~N} \%)$ in the leaves of the inoculated and uninoculated seedlings of Leucaena leucocephala with Rhizobium which fertilized and unfertilized with rock-phosphate

Phosphorus has a key role in nodule development through its basic functions in plants as it is the inorganic moiety of adenosine triphosphate; an energy rich source which affects important cell functions; translocation of sugars, photosynthesis, root growth and other functions which directly or indirectly influence significantly $\mathrm{N}$ fixation by legume plants. Thus, low levels of phosphorus can affect symbiosis by decreasing the supply of photosynthates necessary to the nodule formation which reduces the rate of bacterial growth and the total population of legume-nodulating microorganisms (Moreira et al. 2010). The impact of $\mathrm{P}$ on nodule development and the $\mathrm{N}$ fixation process by legumes was repeatedly reported(Saber et al. 2005). They found that when $\mathrm{P}$ was applied to alfalfa, nodules developed earlier. In high $\mathrm{P}$ soils, nodules were first noted on alfalfa roots 11 days after seeding. Meanwhile, nodules developed about three days later in low P soils. Nodule number, volume, and dry weight could be increased by treating soils with different levels of $\mathrm{P}$. They mentioned also that nodules became pink earlier, developed more quickly, and became active sooner in response to higher $\mathrm{P}$ fertilization. Moreover, Abd-alla 1994 had manifested that even under nonsterile conditions $R$. meliloti strain TAL 1372 was very effective in solubilizing rock phosphate.

Phosphorus increases the yield and nitrogen content in legumes as other studies revealed that $\mathrm{P}$ applied to soils with poor level of $\mathrm{P}$ could increase the percent of $\mathrm{N}$ in legumes, which resulted in greater dry matter. This is believed to be one of the reasons why legumes are dependent on symbiotic $\mathrm{N}$, have a higher $\mathrm{P}$ requirement than grasses which depended on amendment $\mathrm{N}$. This is manifested in view of the fact that, 16 molecules of adenosine triphosphate (ATP) are converted to adenosine diphosphate (ADP) for each molecule of N2 reduced to NH3 (Better 1999).

Concurrent use of fertilization with RF and inoculation with Rhizobium in the nursery may provide typical conditions to produce larger seedlings of high potential to reduce the time needed, thereby help achieve restoration objectives. It is worth notice that the total number of nodules formed depends upon the size and degree of ramification of the root system at the time of inoculation.

The legume-nodulating strains that increased levels of soluble phosphate can improve the efficiency of biological nitrogen fixation, given that nodulated plants require more phosphorus than the plants that use only mineral nitrogen (Silva et al. 2006). This also suggests that the efficiency of nitrogen fixation by the strains approved as inoculants may be related to a greater ability to solubilize low soluble phosphates; however, no studies have experimentally demonstrated this point so far.

Furthermore, several investigations noted that a few nodules were formed in unfertilized seedlings with phosphorus and added that it may be due to the endogenetic differences in Rhizobia (Li et al., 2009; Zhang et al., 2009).

\section{CONCLUSIONS}

Both strains (TAL82 and TAL582) were biotically nitrogen fixing and solubilizing phosphate which resulted in good growth promoting effects. However, strain TAL582 showed better growth promoting effect than TAL82 in Leucaena seedlings. Besides, fertilization with $\mathrm{P}$ promoted nodule formation earlier than control.

It could also be concluded, however, that the capability of rhizobial strain to solubilize phosphorus in plant-growth media is the key criterion to evaluate the efficiency of nodulation and growth of the partner host plant. Therefore, inoculation with strains of Rhizobium and fertilization with $1 \mathrm{~g} \mathrm{RF} / \mathrm{Kg}$ soil are recommended to achieve more plant growth in a relatively short time. 


\section{REFERENCES}

Abd-alla. M.H. 1994.Solubilization of Rock Phosphates by Rhizobium and Bradyrhizobium. Folia Microbiol. 39 (1), 53-56.

Black, C. A. 1965. Methods v of SoilAnalysis.Parts 1 and 2. Agronomy of Soc. Agron Madison.WL 802 pp.

Better Crops. 1999.A Publication of the International Plant nutrition institute. Vol. 83 (No.1).

Boisson-Dernier A. Andriankaja A., Chabaud M., Niebel A., Journet E.-P., Barker D.G. and de Carvalho-Neibel F. 2005. MtENOD11 gene activation during rhizobial infection and mycorrhizalarbuscule development requires a common AT-rich-containing regulatory sequence. Mol. Plant-Microbe Interact. 18:1269-1276.

Deaker, R., R.J. Roughley and I.R. Kenneedy. 2004. Legume seed inoculation technology - a review. Soil Biology\&Biochemistry. 36: 1275-1288.

Donoso, P. J., D. P. Soto, J. E. Schlatter, and C. A. Büchner. 2009. Effects of early fertilization on the performance of Nothofagusdombeyi planted in the Coastal Range of south-central Chile. Cien. Inv. Agr. 36(3):475-486.

Elkhatib, H.A. 2009. Growth and Yield of Common Bean (Phaseolus Vulgaris L.) in Response to Rhizobium Inoculation, Nitrogen and Molybdenum Fertilization. Alex. Sci. Exch. J. 30: 319 - 332.

Glen, Hugh. 2004.Sappi What's in a Name?. Jacana Media. p. 39. ISBN 978-1-77009-040-8.

Journet, E-P, F. de Carvalho-Niebel1, A. Andriankaja, T. Huguet and D.G. Barker. 2006.Rhizobial inoculation and nodulation of Medicago truncatula. Medicago truncatula handbook.PP: 1:6.

Li, J.F., S.Q. Zhang, S.L. Shi and P.H. Huo. 2009. Position and quantity of endogenesis rhizobia in alfalfa plant. Chinese J. Eco-Agriculture. 17: 1200-1205. Li

Mabberley, D.J. 1997.The Plant-Book: A portable dictionary of the ascular plants (2nd ed.). Cambridge, England: Cambridge University Press. p. 406. ISBN 978-0-52141421-0.

Miles, L., A.C. Newton, R.S. DeFries, C. Ravilious, I. May, S. Blyth, V. Kapos, J.E. Gordon. 2006.A global overview of the conservation status of tropical dry forests. J. Biogeogr. 33: 491-505. 4

Miller, S.H., R.M. Elliot, J.T. Sullivan and C.W. Ronson.2007. Host-specific regulation of symbiotic nitrogen fixation in Rhizobium leguminosarum biovar trifolii. Microbiology . 153:3184-3195.

Moreira, F.M.S., T.S.Carvalho and J.O. Siqueira.2010. Effect of fertilizers, lime, and inoculation with Rhizobia and mycorrhizal fungi on the growth of four leguminous tree species in a low-fertility soil. Biology and Fertility of Soils 46: 771-779.

Orwa, C., A.Mutua, R. Kindt, R. Jamnadass and S. Anthony. 2009.Agrofores tree Database: A Tree Reference and Selection Guide. World Agroforestry Center: Nairobi, Kenya.
Razaq, M., P. Zhang, S. Hai-long and Salahuddin.2017. Influence of nitrogen and phosphorous on the growth and root morphology of Acer mono.PLOS ONE journal.pone.12(2). Pp: 1:13.

Rhoades, J.D. 1982. Soluble Salts, Methods of Soil Analysis, Part 2, Chemical and Microbiological Properties. American Society of Agronomy Monograph No. 9.

Richard, L.D. (Ed.). 1954. Diagnosis and Improvement of Salineand Alkali Soils. USDA Handbook 60; Gont. Printing Office, Washington, D. C.

Robert L. W3adys ${ }^{3}$ aw Polcyn and Lech, R. 2002. Nitrate reduction and nitrogen fixation in symbiotic association Rhizobium - legumes. Act BiochimicaPolonica.Vol. 49 No. 2. 537-546.

SAS Institute Inc. 2007. SAS Technical report SAS/STAT software: Changes and Enhancements Users Guide. 2. Version 9.1.3, Fourth Edition, Gary. NC: SAS Institute Inc.

Saber K., N. Labidi, A.Debez and C.Abdelly. 2005. Effect of $\mathrm{P}$ on nodule formation and $\mathrm{N}$ fixation in bean, Agron. Sustain. Dev. 25 pp:389-393.

Shelton, H.M. 1998. The Leucaena genus: New opportunities for agriculture. In Proccedings of the LeucaenaAdaptation. Quality and Farming Systems, Hanoi, Vietnam. 9-14.

Silva, V.N., L.E.S.F. Silva and M.V.B. Figueiredo. 2006. Coinoculation of cowpea seeds with Bradyrhizobium and Paenibacillus and its efficiency on calcium, iron and phosphorus plant absorption. PesquisaAgropecuária Tropical 36: 95-99.

Snedecor, G. W. 1956. Statistical Methods. The Iowa State Univ. Press Ames, Iowa; U.S.A.

Spehn, E.M., M. Scherer-Lorenzen, B.Schmid, A.Hector, M.C. Caldeira, P.G. Dimitrakopoulos, J.A. Finn, A. Jumpponen, G.O'Donnovan and J.S. Pereira. 2002. The role of legumes as a component of biodiversity in a CrossEuropean study of grassland biomass nitrogen. Oikos. 98: 205-218.

Tan, K.Z, O. Radziah, M.S. Halimi, A.R. Khairuddin,S.H. Habib and 1Z.H. Shamsuddin. 2014.Isolation and characterization of Rhizobia and plant growth-promoting rhizobacteria and their effects on growth of rice seedlings. American Journal of Agricultural and Biological Sciences 9 (3): 342-360.

Thrall, P.H., A.-L. Laine, L.M.Broadhurst, D.J. Bagnall and J.Brockwell. 2011. Symbiotic Effectiveness of Rhizobial Mutualists Varies in Interactions with Native Australian Legume Genera. PLoS ONE.6. e23545.

Zhang, S.Q., J.F. Li, S.L. Shi and P.H. Huo. 2009. Quantity and ecological dominance of endogenesis rhizobia in bud seedling and seeds of alfalfa. Chinese J. Grassland.31: 9095.

Zhang, S.Q., J.F. Li, S.L. Shi, P.H. Huo, W.W. Wen, J. Yin, S. Zhou, Q. Liu and Y. Gao. 2013. Phosphate Solubilizing Microorganisms and Phosphate Solubilizing RhizobiumMini Review. Applied Mechanics and Materials. 295: 2328-2332. 


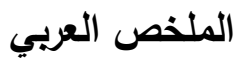

تأثير التلقيح بالرايزوبيا وصخر الفوسفات على الكتلة الحيوية والمحتوى النتروجيني لشتلات الليوسينا

\section{ليوكوسيفالا}

مروة جميل صالح فرحات، أحمد عامر الستاوى ومحمد ربيع عبد المعز شحاته

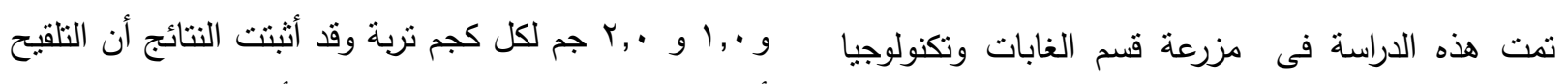

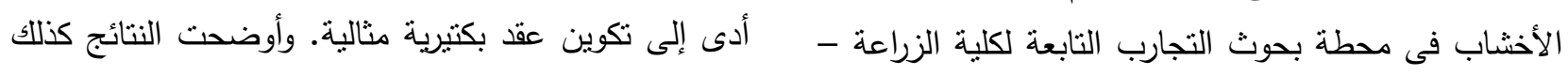

أن السلاله R2 اكثر كفاءه من السلاله R1 فى القدرة على الفي

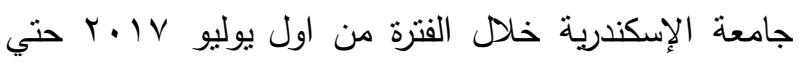
اذابة الفوسفات وتكوين العقد وتثبيت النتروجين وعلى مقاييس السله

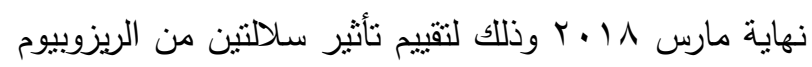

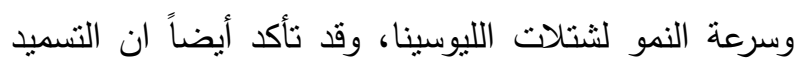
وهما TAL 82 و (R1) ولى TAL582 (R2) على كل مكونات الكنلة

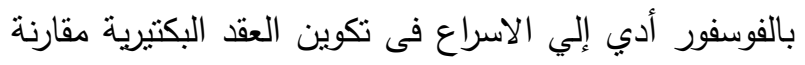

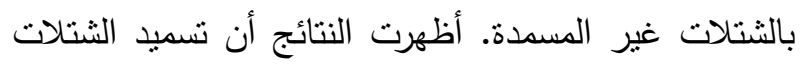

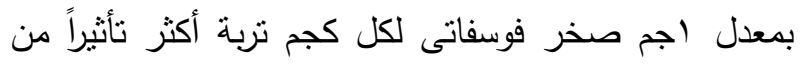

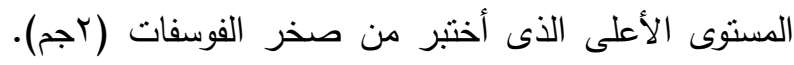

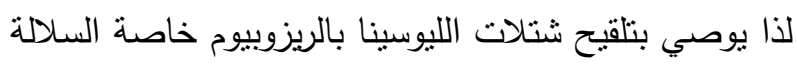
والتسميد بصخر الفوسفات بمعدل ا جم لكل كجم تربة R2 لهدف الحصول على أفضل صفات لنمو الثتلات. الحيوية والمحتوي النتروجيني الكلي فى أوراق شتلات

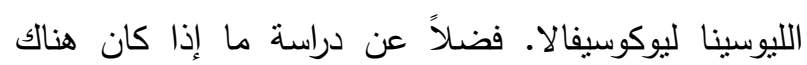
تأثنير لإضافة صخر الفوسفات على نكوين العقد البكتيرية

المثبتة للنتروجين وكفاءة النمو لثنتلات الليوسينا.

تم تلقيح الثتلات بكلتا السلالثين من البكتريا وبعد ثلاثة

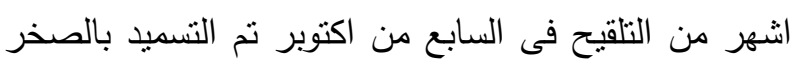

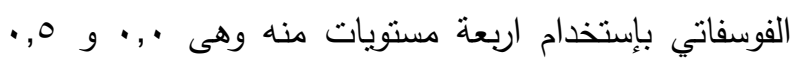

